\title{
Effects of moisture stress on germination and protein synthesis in root tips of cowpea (Vigna unguiculata L. Walp)
}

\author{
E. A. ASIEDU, A. A. POWELL \& T. STRUCHBURY \\ (E. A. A.: CSIR-Crops Research Institute, P. O. Box 3785, Kumasi, Ghana; A. A. P. \& T. S.: Department \\ of Agriculture, University of Aberdeen, Aberdeen AB24 1UA, Scotland)
}

\begin{abstract}
Unpigmented cowpea seeds, TVX 3236 (cream and brown) and IT81S-818 (white), were subjected to more stressful constant moisture conditions $(-0.1$ and -0.15 $\mathrm{MPa}$ ) for 10 days. Germination was reduced from 90 to 43 and 60 per cent, respectively, compared to 90 per cent in those subjected to readily water availability $(-0.0015 \mathrm{Mpa})$. These seeds germinated at $-0.0015 \mathrm{MPa}$ for shorter periods of 12 and $24 \mathrm{~h}$ compared to $48 \mathrm{~h}$ before imposition of stress (-0.15 MPa) for 7 days and showed more reduced final germination, after they had been returned to readily water availability for a further 7 days. However, pigmented seeds, TVX 2724-01F (brown) and IT82D-32 (dark-brown), showed very high germination between 90 and 100 per cent even under stress. The difference between these two groups of seeds, therefore, lies in their abilities to withstand water stress which was related to the differences in damage caused to their embryonic cells as shown by the extent of staining with 2, 3, 5 triphenyl tetrazolium chloride (TTC), and their abilities to synthesize protein after stress by incorporating $\mathrm{L}-\left[4,5-{ }^{3} \mathrm{H}\right]$ leucine into their root tips.
\end{abstract}

Original scientific paper. Received 06 Sep 04; revised 21 Jul 05 .

\section{Introduction}

The inability of viable seeds to germinate, or fail to emerge in the field leads to yield reduction and the need for re-seeding (Hunter \& Erickson, 1952). When seeds are sown in the field, they are often subjected to drought stress which results in poor field emergence (AOSA, 2001). In Ghana and most African countries, farmers sow their seeds soon after rainfall. However, these seeds may be subjected to water stress if the rains do not

\section{RÉSUMÉ}

Asiedu, E. A., Powell, A. A. \& Struchbury, T.: Effets de la pression d'humidité sur la germination et la synthèse de protéine dans les bouts de racine de dolique (Vigna unguiculata $L$. Walp). Les graines de dolique non pigmentées, TVX 3236 (crème et brune) et IT81S-818 (blanche), étaient exposées aux conditions d'humidité constantes plus stressantes $(-0.1$ et $-0.15 \mathrm{MPa})$ pour 10 jours; Ces graines ont subi de germination réduite respectivement de 90 à 43 et $60 \%$ comparé à $90 \%$ en celles qui étaient exposées à l'eau facilement disponible $(-0.0015 \mathrm{Mpa})$. Ces graines germinaient à $-0.0015 \mathrm{MPa}$ pour des périodes plus courtes de 12 et $24 \mathrm{~h}$ comparées à $48 \mathrm{~h}$ avant l'imposition de pression (-0.15 $\mathrm{MPa}$ ) pour 7 jours et montraient de germination final plus réduite après avoir été remises à l'eau facilement disponible pour 7 jours. Les graines pigmentées TVX 2724-01F (brune) et IT82D-32 (brune-foncée), montraient cependant de germination très élevée entre 90 et $100 \%$ même sous les conditions de pression. La différence entre ces deux groupes de graines réside donc dans leurs capacités de résister à la pression d'eau qui était liée aux différences en dégats causés aux cellules embryonnaires comme révélé par l'ampleur de tacher avec 2, 3, 5 chlorure de triphényl tétrazolium (CTT), et leurs capacités de produire synthétiquement la protéiene après la pression par l'incorporation de L-[4, $\left.5-{ }^{3} \mathrm{H}\right]$ leucine dans les bouts de racine. 
1986a,b), cowpea (Legesse \& Powell, 1992; Asiedu \& Powell, 1998; Asiedu \& Powell, 2000; Asiedu et al., 2000), and long bean (Abdullah, Powell \& Matthews, 1992) in which cultivars with unpigmented seed coats showed poor storability, high levels of imbibitional damage to cells, reduced germination, and poor field emergence.

This study aims at determining the differences among cowpea cultivars, differing in seed coat colour, in their response to water stress during germination.

\section{Materials and methods}

The cowpea cultivars used in the study originated from the International Institute of Tropical Agriculture and were produced in Ghana. These were IT81S-818 (a white-seeded, black-eyed cultivar known in Ghana as Bengpla), TVX 3236 (a cream and brown-seeded cultivar), TVX 272401F (a brown cultivar known in Ghana as Soronko), and IT82D-32 (a dark-brown cultivar known in Ghana as Asontem).

Seeds were germinated between two Whatman No. 42 filter papers (measuring $10.5 \mathrm{~cm}$ in diameter) at the matric potentials of $-0.0015,-0.1$ and $-0.15 \mathrm{MPa}$. The matric potentials of the filter papers were determined using the calibration curve of Fawcett \& Collis-George (1967). The filter papers were oven-dried at $105{ }^{\circ} \mathrm{C}$ for $1 \mathrm{~h}$, wrapped in aluminum foil and kept in desiccators. Each filter paper was divided into 10 equal concentric segments, and one seed was placed in each segment, on a circle drawn halfway (by area) across the segments. The water content of the filter papers corresponding to the matric potentials of $-0.0015,-0.1$ and $-0.15 \mathrm{MPa}$ were $163.4,44.0$ and 40.0 per cent, respectively, of the dry weight. Deionized water was sprayed uniformly on the filter papers for the desired matric potentials before the seeds were placed between them after damaged and discoloured seeds had been removed.

Ten seeds per replicate of four were germinated at constant $-0.0015,-0.1$ and $-0.15 \mathrm{MPa}$ for 10 days. Ten additional seeds per replicate were germinated at $-0.0015 \mathrm{MPa}$ for 12,24 , or $48 \mathrm{~h}$ after which they were transferred to a more stressful condition of $-0.15 \mathrm{Mpa}$ which was maintained until the 7 th day of germination. The seeds were then transferred back to $-0.0015 \mathrm{MPa}$ for a further 7 days to determine the final germination. The weights of the filter papers were maintained by periodically removing the seeds and adding more deionized water. Damage to embryonic axes and cotyledons caused by moisture stress were assessed by taking four replicates of 10 seeds of each cultivar and exposing them to $-0.0015,-0.1$, and $-0.15 \mathrm{MPa}$ for $24 \mathrm{~h}$. The embryonic axes were then separated from the cotyledons and both stained using 1 per cent (w/v) 2, 3, 5 triphenyl tetrazolium chloride (TTC) for $3 \mathrm{~h}$ at $30^{\circ} \mathrm{C}$. The extent of vital staining of the axes and cotyledons were assessed and categorized as $100,99-50,49-1$, and 0 per cent stained.

Protein synthesis (incorporation of L- $\left[4,5-{ }^{3} \mathrm{H}\right]$ leucine) in germinating root tips was determined in the white-seeded cultivar, IT81S-818, and the brown-seeded cultivar, TVX 2724-01F, which had earlier been susceptible to and tolerant of moisture stresses, respectively. Three replicates of 20 seeds were germinated between two filter papers in Petri dishes at readily water availability, -0.0015 $\mathrm{MPa}$ for $24 \mathrm{~h}$. Protein synthesis in the germinating root tips was then determined before seeds were transferred to a more stressful condition, -0.15 $\mathrm{MPa}$, for a further 48 and $96 \mathrm{~h}$ and protein synthesis determined again at the end of both periods. At the end of $96 \mathrm{~h}$, the seeds were transferred back to $-0.0015 \mathrm{MPa}$ for a further $72 \mathrm{~h}$ and protein synthesis determined once more.

In another study, two sets of seeds of the tolerant cultivar, TVX 2724-01F (brown-seeded), each containing three replicates of 20 seeds, were germinated at $-0.0015 \mathrm{MPa}$ for $48 \mathrm{~h}$ during which protein synthesis was determined at 24 and $48 \mathrm{~h}$. After $48 \mathrm{~h}$, one set of seeds was transferred to a more stressful condition, $-0.15 \mathrm{MPa}$, for a further $48 \mathrm{~h}$ (i.e., until $96 \mathrm{~h}$ ). The other set was maintained at $-0.0015 \mathrm{MPa}$ for the same period after which protein synthesis was determined. All the studies 
were carried out at 22 to $24{ }^{\circ} \mathrm{C}$.

Protein synthesis was measured by the pulselabeling method and by determining total uptake and incorporation of radioactivity into TCAinsoluble material (Dell' Aquila, 1992). After the required times of germination, samples of 205 $\mathrm{mm}$ root tips were dissected from the seeds, weighed and transferred to the labeling medium $(1.0 \mathrm{ml})$ containing $0.89 \mathrm{ml}$ sterile water, $10 \mu \mathrm{l}$ Penicillin/Streptomycin solution (SIGMA P0906, containing $5000 \mathrm{U} \mathrm{ml}^{-1}$ Penicillin $\mathrm{G}$ and $5 \mathrm{mg} \mathrm{ml}^{-1}$ Streptomycin), and $0.1 \mathrm{ml} \mathrm{L}-\left[4,5-{ }^{3} \mathrm{H}\right]$ leucine (specific activity $3.15 \mathrm{TBq} \mathrm{mmol}^{-1}$; radioactive concentration $\left.0.74 \mathrm{MBq} \mathrm{ml}^{-1}\right)($ Amersham International Plc, product no. TRK 170).

After pulse-labeling for $1 \mathrm{~h}$ at $20^{\circ} \mathrm{C}$ in the dark, the root tips were collected and washed four times with $1 \mathrm{ml}$ ice-cold 80 per cent ethanol containing $12 \mathrm{mM}$ L-leucine and then incubated in $2 \mathrm{ml}$ of the same medium for $20 \mathrm{~min}$. Root tips were then homogenized in a small teflon and glass homogenizer in $1 \mathrm{ml}$ of this medium and centrifuged at $2000 \mathrm{x}$ g. The resulting pellet was re-suspended in $1 \mathrm{ml} 10$ per cent TCA (trichloroacetic acid), heated at $90{ }^{\circ} \mathrm{C}$ for $5 \mathrm{~min}$, and then cooled in ice. This was then filtered through GF/C Whatman glass filters $(3 \mathrm{~cm})$ and washed with $5 \mathrm{ml} 5$ per cent TCA followed by $5 \mathrm{ml}$ 80 per cent ethanol. The filter was dried over silica gel in a desiccator for $24 \mathrm{~h}$. The dried pellet was suspended in $20 \mathrm{ml}$ scintillation fluid and stored in the dark for a further $24 \mathrm{~h}$, after which it was counted in a scintillation counter (Packard Model 2000 CA).

Experimental design was completely randomized block and data were analyzed using the MSTAT statistical package.

\section{Results and discussion}

Germination under constant stress led to reduced final germination in unpigmented seeds compared to the pigmented ones (Table 1). Even when subjected to readily water availability, the earlier the unpigmented seeds were transferred from $-0.0015 \mathrm{Mpa}$ to the more stressful conditions of $-0.15 \mathrm{Mpa}$, the more pronounced the effect of moisture stress in germination (Table 2). The pigmented cultivar showed a greater ability to retain viable cells in the embryonic axes and cotyledons as indicated by high levels of vital staining using TCC (Table 3), and also to synthesize protein by incorporating large quantities of L- $\left[4,5-{ }^{3} \mathrm{H}\right]$ leucine into their root tips (Fig. 1a.). Protein synthesis in the first set of pigmented seeds transferred to a more stressful condition, $-0.15 \mathrm{MPa}$ for $48 \mathrm{~h}$, after $48 \mathrm{~h}$ readily water availability remained constantly low (7 $\mathrm{DPM} / \mathrm{FW} \times 10^{4}$ ) of L- $\left[4,5-{ }^{3} \mathrm{H}\right]$ leucine; whereas the second set, which remained unstressed for the same period, showed a dramatic increase from 7 to $45 \mathrm{DPM} / \mathrm{FW} \times 10^{4}$ (Fig. $1 \mathrm{~b}$ ).

The equal and unchanging levels of L-[4, 5$\left.{ }^{3} \mathrm{H}\right]$ leucine during the stress period from 24 to $120 \mathrm{~h}$ (Fig. 1a) showed that protein synthesis in

TABLE 1

Germination (\% Radicle Emergence) After 10 Days at Constant Matric Potential

\begin{tabular}{lcccc}
\hline & \multicolumn{4}{c}{ Cowpea variety } \\
\cline { 2 - 5 } Matric potential (Mpa) & $\begin{array}{c}\text { TVX 3236 } \\
\text { (Cream and brown) }\end{array}$ & $\begin{array}{c}\text { IT81S-818 } \\
\text { (White) }\end{array}$ & $\begin{array}{c}\text { TVX 2724-01F } \\
\text { (Brown) }\end{array}$ & $\begin{array}{c}\text { IT82D-32 } \\
\text { (Dark-brown) }\end{array}$ \\
\hline-0.0015 & $90.0 \mathrm{~b}$ & $90.0 \mathrm{~b}$ & $100.0 \mathrm{a}$ & $100.0 \mathrm{a}$ \\
-0.10 & $55.0 \mathrm{~d}$ & $90.0 \mathrm{~b}$ & $100.0 \mathrm{a}$ & $100.0 \mathrm{a}$ \\
-0.15 & $43.0 \mathrm{e}$ & $90.0 \mathrm{~d}$ & $90.0 \mathrm{~b}$ & $100.0 \mathrm{a}$ \\
\hline
\end{tabular}

Means of columns and rows followed by different letters differ significantly $(P<0.05)$ by Duncan's Multiple Range Test 
TABLE 2

Germination (\% Radicle Emergence) of Seeds Subjected to Moisture Stress at -0.15 MPa After Transfer From $-0.0015 \mathrm{MPa}$

\begin{tabular}{ccccc}
\hline $\begin{array}{c}\text { Time of transfer } \\
\text { (h) }\end{array}$ & \multicolumn{4}{c}{ Cowpea variety } \\
\cline { 2 - 5 } & $\begin{array}{c}\text { TVX 32336 } \\
\text { (Cream and brown) }\end{array}$ & $\begin{array}{c}\text { IT81S-818 } \\
\text { (White) }\end{array}$ & $\begin{array}{c}\text { TVX 2724-01F } \\
\text { (Brown) }\end{array}$ & $\begin{array}{c}\text { IT82D-32 } \\
\text { (Dark-brown) }\end{array}$ \\
\hline 48 & $90.0 \mathrm{~b}$ & $80.0 \mathrm{c}$ & $100.0 \mathrm{a}$ & $100.0 \mathrm{a}$ \\
24 & $75.0 \mathrm{~cd}$ & $75.0 \mathrm{c}$ & $100.0 \mathrm{a}$ & $95.0 \mathrm{a}$ \\
12 & $65.0 \mathrm{e}$ & $70.0 \mathrm{c}$ & $100.0 \mathrm{a}$ & $95.0 \mathrm{a}$ \\
\hline
\end{tabular}

Means of columns and rows followed by different letters differ significantly $(P<0.05)$ by Duncan's Multiple Range Test

TABLE 3

Axes or Cotyledons With Complete Vital Staining (\%) After Seeds Had Imbibed Water at Either -0.0015 MPa or $-0.15 \mathrm{MPa}$ for $24 \mathrm{~h}$

\begin{tabular}{lrrrr}
\hline Cowpea variety & & Matric potential (MPa) & -0.15 \\
\cline { 2 - 5 } & & -0.0015 & Axes & Cotyledons \\
\hline TVX 3236 (Cream and brown) & 90 & Cotyledons & 80 & 78 \\
IT81S-818 (White) & 100 & 100 & 60 & 95 \\
TVX 2724-01F (Brown) & 100 & 100 & 70 & 100 \\
IT82D-32 (Dark-brown) & 90 & 95 & 90 & 95 \\
\hline
\end{tabular}

pigmented and unpigmented seeds was equally retarded under stress. The pigmented cultivar germinated well after stress because of its ability to retain viable embryonic cells as shown by vital staining using TCC (Table 3), and to synthesize large amounts of protein by incorporating L-[4,5${ }^{3} \mathrm{H}$ ] leucine into their root tips (Fig. 1a).

The inability of the second set of pigmented seeds to show increases in incorporating L- $[4,5$ $\left.{ }^{3} \mathrm{H}\right]$ leucine into their root tips during the period of reduced water availability underscores the need for uninterrupted supply of water to cowpea during germination and seedling growth, even in drought-tolerant cultivars. These results agree with those of similar studies in which protein synthesis ceased as stress occurred but started immediately the seeds were hydrated (Bewly \& Black, 1994; Dhindsa \& Cleland, 1975; Dell' Aquila \& Taranto, 1986; Dell'Aquila, 1992; Lalonde \& Bewly, 1986; Dell' Aquila \& Bewly, 1989). Thus, although germination and root growth (incorporating L- $\left[4,5-{ }^{3} \mathrm{H}\right]$ leucine into root tips) in both seed types were equally retarded under water stress, the pigmented cultivar had a greater ability to retain viable cells and recover at the resumption of readily water availability. Despite its ability to tolerate water stress, the pigmented cultivar stagnated during the period of reduced water availability, underscoring the need for uninterrupted water supply during germination of cowpea, even in stress-tolerant cultivars. 


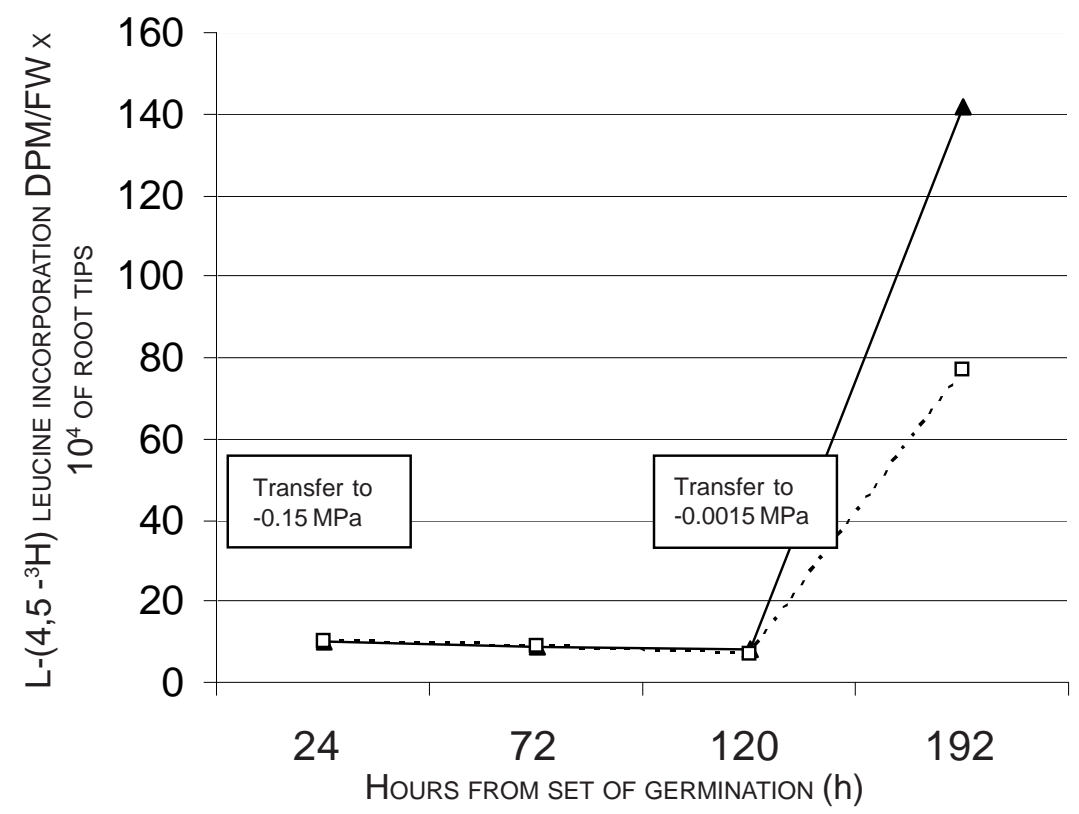

Brown cultivar

White cultivar

Fig.1a. Incorporation of DPM/FW $\times 10^{4}$ of $\mathrm{L}-\left[4,5^{-}{ }^{3} \mathrm{H}\right]$ of leucine into the root tips of white-seeded $(\square)$ and brown-seeded $(\boldsymbol{\Delta})$ cowpeas after seeds had been exposed to readily water availability $(-0.0015 \mathrm{MPa})$ for (n) readily water availability up

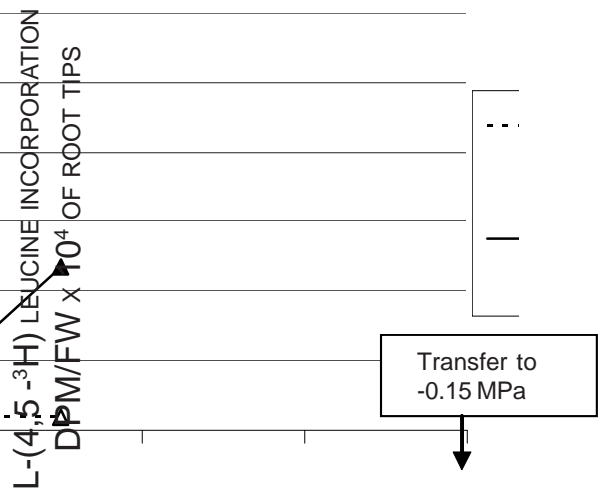

Stressed brown seed

\section{$24 \quad 48 \quad 96 \quad 144 \quad 192$}

HOURS FROM SET OF GERMINATION (h)

Fig. 1b. Incorporation of DPM/FW $\times 10^{4}$ of $\mathrm{L}-\left[4,5-{ }^{3} \mathrm{H}\right]$ of leucine into the root tips of a pigmented cowpea cultivar (TVX 2724-01F) initially exposed to readily water availability $(-0.0015 \mathrm{MPa})$ until $48 \mathrm{~h}$ before subjecting one set to water stress $(-0.15 \mathrm{MPa} ; \triangle)$ and readily water availability $(-0.0015 \mathrm{MPa} ; \mathbf{\Delta})$ up to $96 \mathrm{~h}$. 


\section{REFERENCES}

Abdullah, W. D., Powell, A. A. \& Matthews, S. (1992) Prediction of the storage potential of long bean (Vigna sesquipedalis L. Fruhw) seed in the tropics. Seed Sci. Technol. 20, 141-147.

Asiedu, E. A. \& Powell, A. A. (1998) Comparison of the storage potential of cultivars of cowpea (Vigna unguiculata L. Walp.) differing in seed coat pigmentation. Seed Sci. Technol. 26, 211-221.

Asiedu, E. A. \& Powell, A. A. (2000) Responses of cowpea cultivars to water stress during germination Trop. Sci. 40, 177-183.

Asiedu, E. A., Struchbury, T. \& Powell, A. A. (2000) Cowpea seed coat chemical analysis in relation to storage seed quality. Afr. J. Crop Sci. 8(3), 283294.

AOSA (2001) Seed vigour testing handbook. Proceedings of the Association of Official Seed Analysts. Contribution No. 32, 1-93.

Bewly, J. D. \& Black, M. (1985) Seeds: Physiology of development and germination. New York and London: Plenum Press. pp. 89-133.

Dell'Aquila, A. \& Taranto, G. (1986) Cell division and DNA-synthesis during osmopriming treatment and following germination in aged wheat embryos. Seed Sci. Technol. 14, 333-341.

Dell'Aquila, A. \& Bewley, J. D. (1989) Protein synthesis in the axes of polyethylene glycol-treated pea seed and during subsequent germination. J. exp. Bot. 40, 1001-1007.

Dell'Aquilla, A. (1992) Water uptake and protein synthesis in germinating wheat embryos under the osmotic stress of polyethylene glycol. Ann. Bot. 69, $167-171$
Dhindsa, R. S. \& Cleland, R. E. (1975) Water stress and protein synthesis. 1. Differential inhibition of protein synthesis. Pl. Physiol. 55, 778-781.

Fawcett, R. G. \& Collis-George, N. (1967) A filter paper method for determining the moisture characteristics of soil. Australian Journal of Experimental Agriculture and Animal Husbandry 7, 162-167.

Heydecker, W. (1977) Stress and seed germination: An agronomic view. In The physiology and biochemistry of seed dormancy and germination (ed. A. A. Khan), pp. 237-282. North-Holland Publishing Company. Amsterdam, New York, Oxford.

Hunter, J. R. \& Erickson, A. E. (1952) Relationship of seed germination to soil moisture tension. Agron. J. 44 (3), 107-109. Planta 167, 504-510.

Lalonde, L. \& Bewley, J. D. (1986) Patterns of protein synthesis during the germination of pea axes, and effects of an interrupting desiccation period. Planta 167, 504-510.

Legesse, N. \& Powell, A. A. (1992) Comparisons of water uptake and imbibition damage in eleven cowpea cultivars. Seed Sci. Technol. 20, 173-180.

Powell, A. A., Oliveira, M. de A. \& Matthews, S. (1986a) Seed vigour in cultivars of dwarf French bean (Phaseolus vulgaris L.) in relation to the colour of the testa. J. agric. Sci., Camb. 106, 419-425.

Powell, A. A., Oliveira, M. de A. \& Matthews, S. (1986b). The role of imbibition damage in determining the vigour of white and coloured seed lots of dwarf French bean (Phaseolus vulgaris L). J. expl Bot. 37,716-722. 